\title{
Internet Reviews
}

\section{ECHO Science \& Technology Virtual}

Center. Access: http://echo.gmu.edu/ center/.

Funded by the Alfred P. Sloan Foundation, the ECHO Science and Technology Virtual Center is based at George Mason University's Center for History and New Media and provides an excellent entry into this wide-ranging field of study. The authors clearly identify three primary audiences for this eclectic, interesting, and many times entertaining site: historians of science and technology seeking further information on the use of technology to assist in crafting similar projects, the human subjects responsible for much of this knowledge-those living scientists and researchers who have contributed so much to the world's current base of scientific knowledge, and students and others interested in this subject. Due to its broad nature, I would also suggest the site as a general reference starting point for librarians seeking science-related materials.

ECHO might serve purely as a quality Web subject directory for many academic librarians seeking enhanced access to scientific materials and topics, although the site's defined purpose is more specialized than this.

ECHO would make a wonderful addition to any academic librarian's Internet search page. The authors classify the site according to a number of broad categories, including but not limited to the earth, physical, life, and medicine/behavioral sciences, aviation, engineering, and computers. All entries within categories are alphabetical and the majority of them include annotations. Many of the links are housed on Web servers running from academic institutions and professional organizations. Using ECHO, one can locate information on topics ranging from enzyme nomenclature databases to classifications of flowering plants to a "Determination of Latitude by Francis Drake on the Coast of California in 1579." Other useful links include lists of academic programs in the history of science, email lists on scientific topics, and the current featured site- "The Barbara McClintock Pa- pers: A Profile in Science at the National Library of Medicine."

The ECHO Science \& Technology Virtual Center will prove invaluable to a wide range of academic audiences. Its excellent structure, clearly written pages, and exemplary Web links provide a valuable service to anyone seeking scientific information, from student library users to teaching and research faculty. And an added bonus - it is simply interesting and fun to explore.-Jobn Creech, Central Washington University, Jobn.Creech@ cwu.edu

The Costume Gallery. Access: http://www.

costumegallery.com/.

Bringing the long-standing print tradition of compiling fashion illustrations to the Internet, the Costume Gallery contains "over 1,000 Web pages and 2,500 images of fashion and costume." Intended for use by authors, screenwriters, educators, and students, fashions on the site range from the Byzantine and Medieval eras through the 20th century and cover all corners of the world.

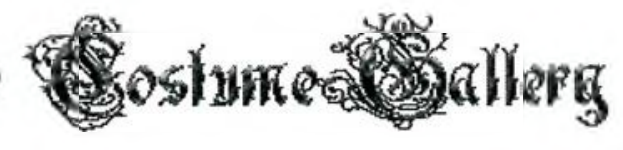

Penny E. Dunlap Ladnier, a costumer by education and vocation, first created the Historic Costume Research Web site "to educate people about costumes" while a student at Virginia Commonwealth University in the mid'90s. After she graduated, she merged the earlier site into the Costume Gallery.

The Costume Gallery is divided into five parts. Of most interest to librarians are "Library," "Product Palace," and "Designer's Hall." "Library" is divided into three shelves: "Fashion Articles to Research" which includes a few sewing reference books, but is mostly a handful of magazines from the turn of the

Joni R. Roberts is associate university librarian for public services and collection development at Willamette University, e-mail: jroberts@willamette.edu, and Carol A. Drost is associate university librarian for technical services atWillamette University, e-mail:cdrost@willamette.edu 
century such as Ladies Home Journal and Delineator, "Portfolio of Costumes," and "Research by Time and Topic." The third shelf is probably the most useful to librarians, as it provides links to fashion Web sites by time period, culture, and fashion designer. "Product Palace" lists links to "businesses that provide products and services related to the costume" while "Designer's Hall" lists "websites owned by costume designers." In addition, "Costume Classroom" offers online classes on how to make costumes and "Courtyard" provides recreational fun with costuming such as fashion postcards and paper dolls and an annual online costume ball.

Searching the Costume Gallery is straightforward, but not always easy. The categories are broad and require users to browse a hierarchy to find what they need. Many icons that seem like they should provide navigation links go nowhere, so it can be awkward to move from page to page, especially since there is no search mechanism. Each link opens a new browser window, so users can very quickly be working with a dozen open pages.

As with quote books, the best resource for costumes is the one where you find the costume that you need. The Costume Gallery is in fact one of the best available on the Web, and it complements the traditional print reference sources very nicely. For a list of more costume Web sites to consult if the costume you seek is not in the Costume Gallery, consult "GladRags.com," a guide to fashion and costume compiled by Monica Fusich for CERL News in April 1999 (http://www.ala.org/acrl/ resapr99.html)._Mark Emmons, University of NewMexico,emmons@unm.edu.

\section{American Museum of Natural History Congo Expedition 1909-1915. $A C$ -} cess: http://diglib1.amnh.org.

The Congo Expedition 1909 to 1915 Web site is produced by the Digital Library of the American Museum of Natural History $(\mathrm{AMNH})$. It provides a unique and informative venue for researchers, educators and students alike. The site details the Congo Expedition carried out by AMNH scientists Herbert Lang and James Chapin from 1909 to 1915. The expedition's mission was to gather biological and ethnographic materials to be displayed at the museum. Many of these materials, along with diaries, field notes and photo- graphs, have been digitally documented and made available to the public.

The site is designed to interest both the layperson and the scholar. "Introduction," "Readings," and "Gallery" offer an array of stimulating multimedia, including stereophonic photographs, video and audio clips, and interactive Geographic Information Systems. Many of these features require a plug-in, which may be easily downloaded. "Scientific Publications," "Search," and "Resources" primarily serve the scientific community, offering several avenues for research into the AMNH's archival databases.

The narrated slide show in the introduction provides historical context for the Congo Expedition and sets the mood for the highly interactive nature of the site. This is worth the few minutes it may require to load. Other large files in the site load faster. The Map Gallery, for instance, uses TilePic and quickly displays historical maps of Africa and the Congo Region.

The primary database is accessed through the search section of the site. The search capability is relatively sophisticated, offering nine search fields and the option to limit by material type. Among the digitized materials featured are Lang and Chapin's diaries and field notes, which have been reproduced digitally and transcribed for indexing; 2,000 of the 9,000 photographs taken by Lang during the expedition; and descriptions of more than 4,000 anthropological objects, over half of which have been photographed.

The AMNH's Digital Library should be commended on its efforts to provide a stimulating learning environment, a well-indexed and fully searchable archival database, and comprehensive bibliographies. These materials have tremendous educational, historical, and scientific value. The site however, does not meet the Priority One Accessibility checkpoints established in the W3C Web Content Accessibility Guidelines. In spite of this, the site is highly recommended for the student, educator, scientist, or historian.-Sheri Webber, Purchase College, SUNY, sheri.webber@purchase.edu

("Washington Hotline" continued from page 368)

Hollings's bill is cosponsored by Ted Stevens (R-Arkansas), Daniel K. Inouye (DHawaii), John B. Breaux (D-Louisiana), Bill Nelson (D-Florida), and Dianne Feinstein (DCalifornia). 


\section{Essential Resources for Your Library}

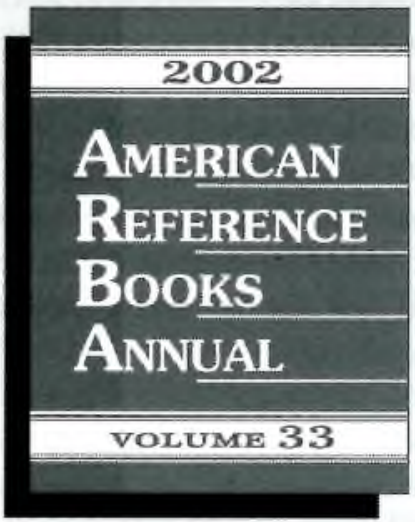

\section{American Reference Books Annual 2002}

Volume 33

REVIEWS OF PREVIOUS EDITIONS:

"When it comes to publications that can be used in reference work and as a collection development tool, few titles stand out as clearly as American Reference Book Annual (ARBA)." -Collection Building

"The most comprehensive collection of authoritative reviews of English-language reference materials."-Technology Connection

2002 xxvii, 802p. 7x10 cloth ISBN 1-56308-911-4 \$120.00

\section{Libraries in the Information Age} An Introduction and Career

\section{Exploration}

Denise K. Fourie AND David D. DOWell

Library and Information Science Text Series

2002 xiv, 304p. 6x9

cloth ISBN 1-56308-635-2 \$55.00

paper ISBN 1-56308-634-4 \$45.00

Issues for Libraries and Information Science in the Internet Age

Bruce A. Seuman

2001 xviii, 227p. $6 \times 9$ paper

ISBN 1-56308-805-3 $\$ 45.00$

Libraries in the Information Age

An Introduction and Career Exploration

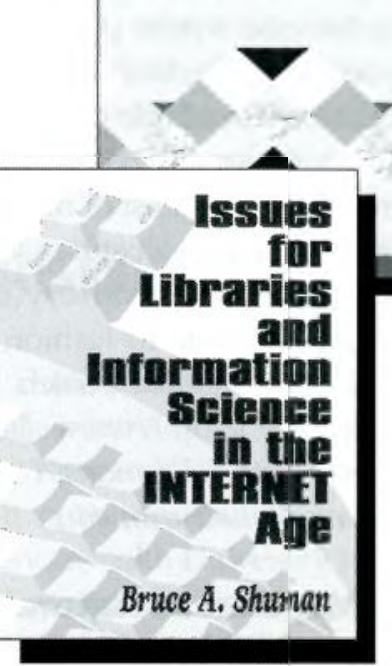

\section{The Social Sciences}

A Cross-Disciplinary Guide to Selected Sources

3d Edition - Nancy L. Herron, General Editor

Library and Information Science Text Series

June $2002 \mathrm{ca} .400 \mathrm{p}$. $7 \times 10$

cloth ISBN 1-56308-985-8 \$75.00

paper ISBN 1-56308-882-7 $\$ 60.00$

VISIT US AT

\section{ALA!}

\section{Libraries Unlimited}

Customer Service Group, Dept. A442 P.O. Box 5007 - Westport, CT 06881

Order toll-free 800-225-5800 - Fax 203-750-9790 * www.lu.com 